\title{
STUDIES IN CRYPTOCARYA
}

\section{(LAURACEAE) I}

\author{
D. G. Frodin
}

(Received 1972,

revised 1975)

\section{ABSTRACT}

Frodin, D. G. (Department of Biology, The University of Papua New Guinea, University, Papua New Guinea) 1976. Studies in Cryptocarya I. Telopea I (3): 217-224.-Cryptocarya meissneri F. Muell., C. bidwillii Meisn. and C. moretoniana Meisn. have been re-examined. The following conclusions have been drawn: (i) the name $C$. meissneri and its replaced synonym C. hypoglauca var. attenuata Meisn. are typified by a specimen of $C$. glaucescens $\mathrm{R}$. $\mathrm{Br}$.; consequently $C$. meissneri auct. is described as $C$. meisnerana, sp. nov. (p. 223); (ii) $C$. bidwillii is a distinct species previously confused with other taxa; (iii) $C$. moretoniana is a form of $C$. glaucescens $\mathrm{R}$. Br. A key and formal treatment are provided for $C$. glaucescens, $C$. microneura, C. bidwillii and C. meisnerana (p. 221).

\section{INTRODUCTION}

This paper represents an attempt to resolve some questions pertaining to the classification of certain eastern Australian species of Cryptocarya R. Br. (Lauraceae). The first of these arises from the reduction by Kostermans $(1969, \mathrm{p} .468)$ of the taxon, known universally and without question for over 100 years as Cryptocarya meissneri F. Muell., to the little-known C. bidwillii Meisn. This, in turn, leads to a second, and rather older, question: what is the true identity of the taxon designated by the name $C$. bidwillii Meisn., as well as that known as $C$. moretoniana Meisn., with which the former has sometimes been confused? In addition, it appears that $C$. meissneri is typified by $C$. hypoglauca Meisn. var. attenuata Meisn., the type specimen of which represents a mere form of $C$. glaucescens $\mathrm{R}$. Br.; this necessitates a re-assessment of the nomenclature of $C$. "meissneri" as usually understood. In order to minimize possible confusion in future, and with regard to Kostermans' action noted above, I have treated $C$. "meissneri" here as a new species, viz. C. meisnerana Frodin. The necessary documentation is given elsewhere in this paper.

In connection with the analysis of these questions, a systematic treatment of C. bidwillii Meisn., C. glaucescens Meisn., C. meisnerana Frodin and C. microneura Meisn. is presented as an appendix, together with a key. It is hoped that this will clarify some of the confusion surrounding these species and serve also as a contribution towards a much-needed revision of the genus in Australia and nearby regions.

The impetus for this study came early in 1970 when Mr D. J. McGillivray, then Australian Botanical Liaison Officer at Kew, drew my attention to the difficulties caused by the above-mentioned reduction by Kostermans. Prior to this, the present author had assembled extensive notes on a large number of Cryptocarya species during visits to the Herbaria at Brisbane, Sydney and Melbourne in 1966-67; later on relevant material at Bogor (including Meisner Herbarium specimens on loan from the New York Botanical Garden) and Kew, as well as microfiche reproductions of specimens in the Candollean Prodromus herbarium, were examined. All four species involved in the present study were also observed in the field during a short visit to northern New South Wales in 1967.

\section{The identities of Cryptocarya bidwillii Meisn. and C. moretoniana Meisn.}

Cryptocarya bidwillii was first described by Meisner (1864, p. 74) from somewhat imperfect material collected by Bidwill at Wide Bay, SE. of Maryborough (now in southern Queensland). In his Appendix to the Laurineae, Meisner (l.c., p. 508) added without further comment a citation for a specimen collected at Hastings River, Port Macquarie, in New South Wales and communicated by F. Mueller. 
Cryptocarya moretoniana was described by Meisner at the same time (l.c., p. 74) from material supposedly collected by A. Cunningham at Moreton Bay, Queensland. The essential attributes are herewith quoted from his original diagnosis: "foliis coriaceis.... nervo supra insculpto subtus prominulo;.... fructus globosus, 6 lin. diam. [italics mine]". He also noted that the leaves, at least in the dry state, were usually more or less the same colour on both surfaces but sometimes paler beneath, and were lanceolate, with acute tips and attenuate bases.

The earliest revisionary treatment covering the above two taxa is that of Bentham $(1870$ p. 297$)$. They are therein reduced to Cryptocarya glaucescens $\mathrm{R}$. Br. $C$. moretoniana became - with the addition of a collection of Leichhardt's from Archer's Creek [NW. of Brisbane] ${ }^{1}$ - the basis of var. nitida Benth. ${ }^{2} C$. bidwillii was placed immediately following this variety, still under the general heading of $C$. glaucescens. Its status was left in some doubt, as follows: " $C$. bidwillii . . ., of which the specimens from Wide Bay, Bidwill, are in young fruit only, and not satisfactory, may be the same variety." Of $C$. glaucescens in general, Bentham noted: "All the above varieties run much one into the other, and in view of the large number of specimens $I$ have had before me, it seems impossible to consider any of them as species permanently distinct". Subsequent to these words from the Master, the two taxa sank into virtual oblivion for several decades. Hardly a mention of them exists in the major floristic works of Mueller (1882, 1889), Bailey (1883), Moore \& Betche (1893), Bailey (1901, 1913), Maiden \& Betche (1916) and Francis (1929). They are mentioned under $C$. glaucescens by Bailey in the Queensland Flora but this is simply a reiteration of Bentham's account of 1870 .

The first hint that Bentham's concept of Cryptocarya glaucescens may have been too broad was given by Maiden and Betche (1895), when they showed that C. microneura Meisn. was in all respects a good species. A fuller treatment of that species subsequently appeared in Maiden's Forest Flora (1907, p. 144). However, no further light was shed either on $C$. bidwillii or on $C$. moretoniana except for a remark by Maiden to the effect that it would be desirable to submit these varieties to rigid re-examination (l.c., p. 125, under C. glaucescens).

Francis, in the second edition of his Australian Rain-forest Trees (1951), considered $C$. glaucescens var. nitida Benth. to be a distinct species ${ }^{3}$, albeit very close to $C$. microneura; for this taxon he took up the name $C$. moretoniana, since this, and not $C$. bidwillii, was the basis for Bentham's variety. Francis described his plants as having rather coriaceous shining leaves. This usage of $C$. moretoniana was subsequently taken, up and a full description provided, by Floyd \& Hayes (1960) for an apparently little-known but distinct species with a limited distribution in northern New South Wales and with foliar characteristics resembling those of Francis's plants.

The first serious effort to clarify those Australian species of Cryptocarya was made by $C$. T. White. In manuscript notes made in Kew in 1939 (now placed with the material of $C$. glaucescens in BRI) he considered that $C$. moretoniana was simply a form of $C$. glaucescens with acute leaves and that $C$. bidwillii was a good species, distinct from $C$. microneura.

After studying all relevant material in BRI, K, MEL and NSW, as well as my own collections made at Glen Ugie Peak near Grafton, N.S.W., I have found White's judgements to be correct. Indeed, material collected from Glen Ugie Peak (and

1 The specimen cited by Bentham and located at $K$ is a probable duplicate of that cited by Meisner $(1864$, p. 508) under $C$. microneura and preserved in G-DC.

2 Var. nitida was described by Bentham as follows: "Leaves coriaceous and shining with fine veins, green on both sides or scarcely glaucous."

${ }^{3}$ By this time considerably more herbarium material had become available, much of which Francis himself had gathered. 
first identified as $C$. moretoniana by A. G. Floyd) agrees very well with the type of C. bidwillii [Bidwill $38(\mathrm{~K})$, from the Wide Bay district in Queensland]. Consequently, the latter name must now be applied to the species with relatively small, somewhat shining, yellow-green, coriaceous and non-glaucous leaves without prominently reticulated venation or a sunken midrib. This species occurs locally on drier ridges in dry vine forest or scrub from Glen Ugie Peak northwards.

Cunningham $48 / 1829(\mathrm{~K})$, a probable isotype of C. moretoniana ${ }^{4}$, is certainly only a state of $C$. glaucescens. The same may be said for the holotype in G-DC (as observed in microfiche reproduction). As noted by Meisner himself, the leaves in the dry state have the midrib sunken on the upper surface, just as in material of $C$. glaucescens in the proper, usually accepted sense. The main difference is that the tips of the leaves are sharply acute rather than obtuse as in "normal" leaves of $C$. glaucescens. However, field studies show that both leaf forms occur in the phenology of single trees; it is in the sapling phase that these acute leaves more commonly appear. Furthermore, examination of the fruits in Cunningham's specimen cited above indicates that, although diseased and somewhat immature, they would have assumed the depressed-globose shape so characteristic of $C$. glaucescens amongst Australian species ${ }^{5}$.

\section{The relationship between $\mathrm{C}$. bidwillii Meisn. and $\mathrm{C}$. meissneri $F$. Muell.}

As noted in the Introduction, Kostermans (1969, p. 468) has created a measure of confusion by his use of the name $C$. bidwillii Meisn. for the species long known as C. meissneri $\mathrm{F}$. Muell., which latter name was thereupon reduced to synonymy. I shall here discuss the possible source of this confusion as well as show that Kostermans' action is untenable.

The union of $C$. meissneri with $C$. bidwillii, as proposed by Kostermans, evidently has as its basis the specimen at G-DC (represented also at $\mathrm{K}$ and $\mathrm{MEL}$ ) originally gathered at Hastings River [New South Wales], communicated by Mueller and cited by Meisner (1864, p. 508) as an additional record for C. bidwillii. However, careful examination of specimens at $\mathrm{K}$ and MEL, as well as the microfiche record of that at G-DC, shows this specimen to be $C$. meissneri as always understood in Australia. To me, there is no doubt that $C$. meissneri auct. is amply distinct from $C$. bidwillii at specific level. On the other hand, Kostermans-somewhat inexplicably-seems to have considered the above specimen (G-DC) to be the type of $C$. meissneri as well as representing authentic $C$. bidwillii; accordingly, he united both taxa under the latter, earlier name. Yet this author must surely have seen the true holotype of C. bidwillii, because I found it to have been annotated by him in 1967-as C. microneura Meisn. It seems, though, that he subsequently overlooked this, for in his paper he cites that specimen, Bidwill 38, under C. bidwillii without any reference to C. microneura (1969, p. 468). It might be added that Meisner added no further descriptive notes when citing the specimen of $C$. meissneri auct. from Hastings River; it therefore has no standing for nomenclatural purposes and furthermore, as will be shown in the next section, is not even the holotype of $C$. meissneri F. Muell.

\section{The status of Cryptocarya meissneri $F$. Muell.}

While resolving the status of $C$. bidwillii and $C$. moretoniana, my attention was drawn to problems surrounding the name $C$. meissneri $F$. Muell. As pointed out in the preceding paragraph, the specimen from Hastings River-which represents the species known as $C$. meissneri-cited by Meisner (l.c.) and referred to by Kostermans (l.c.) has no status as a type. I shall here show that $C$. meissneri auct. is without a valid name, and as contemporary references and diagnoses are insufficient, I propose to describe this species as new (see p. 223).

4 This number was annotated by Bentham as C. glaucescens var. nitida Benth.

${ }^{5}$ In the past, a number of other acute-leaved specimens of $C$. glaucescens at Kew have been annotated as $C$. moretoniana. 
It was Mueller (1866, p. 170) who apparently first recognized that the abovementioned collection, together with other material from the Macleay River, represented an undescribed species, distinct from $C$. bidwillii. In describing this material as $C$. meissneri, he included a reference to $C$. hypoglauca Meisn. var. attenuata Meisn., which he appears to have thought had been based on a duplicate of the specimen from Hastings River. I can find no other explanation for Mueller's citation of that varietal name. However, as previously indicated, Meisner had in fact referred the specimens from Hastings River to $C$. bidwillii.

In order to determine the identity of Cryptocarya hypoglauca var. attenuata, the reproduction (on microfiche) of the holotype in G-DC was checked independently by Mr D. J. McGillivray and the present author. The specimen concerned proved to be another of those from the Hastings River communicated by Mueller, representing a form of C. glaucescens $\mathrm{R}$. Br.

Unfortunately the protologue for $C$. meissneri is based on two different elements: the type specimen of $C$. hypoglauca var. attenuata which is $C$. glaucescens, and two specimens of the species universally understood as $C$. meissneri. The latter, like C. glaucescens, is quite a common rainforest species.

Two possible ways of resolving this problem appear to exist. One is to apply the name $C$. meissneri in the sense probably intended by Mueller, i.e. to the cited specimens from the Hastings and Macleay Rivers, the other is to restrict the use of that name to the type of C. hypoglauca var. attenuata. I have chosen the second approach, so as to prevent further possible confusion. The specimen, 'Hastings River, Mueller s.n.' (G-DC) is therefore selected as the Lectotype of the name C. meissneri F. Muell. This results in the reduction of the name $C$. meissneri to a synonym of $C$. glausescens and leaves the species long known by the former name without any epithet. Since no alternative names are available, and because Mueller provided a rather perfunctory diagnosis, I have decided to treat this taxon as a new species, Cryptocarya meisnerana Frodin (see p. 223).

\section{ACKNOWLEDGEMENTS}

I wish first to express my thanks to Mr D. J. McGillivray, of the National Herbarium of New South Wales, for bringing the question of the correct identity of these species of Cryptocarya to my attention at a time when I was in a position to examine relevant type material, and for suggesting possible solutions. I also appreciate the helpful suggestions by Dr M. D. Tindale regarding presentation of the manuscript. Grateful thanks are also due to the responsible authorities of the following organizations for permission to consult relevant material: National Herbaria of Victoria and New South Wales; the Queensland Herbarium; the Herbarium Australiense of CSIRO; the Commonwealth Forestry and Timber Bureau and the State Forestry Office, both at Atherton, North Queensland; and the Herbarium of the Royal Botanic Gardens, Kew. In addition, special thanks are due to Mr A. G. Floyd, of the Forestry Commission of N.S.W., at Coff's Harbour, for conducting me into the rain forests of northern New South Wales; and to Dr L. J. Webb and Mr J. G. Tracey of the Rain Forest Ecology Unit, CSIRO, Brisbane, the late Dr Caroline K. Allen of the New York Botanical Garden and Mr B. Hyland of the Commonwealth Forestry and Timber Bureau research unit at Atherton, North Queensland, for discussion and advice on Cryptocarya in general.

\section{LITERATURE CITED}

Anderson, R.H., 1947-The Trees of New South Wales. ed. 2. Government Printer, Sydney.

Anderson, R.H., 1956 (1957)--Ibid., ed. 3.

Anderson, R.H., 1968-Ibid., ed. 4. 
Bailey, F.M., 1883-A Synopsis of the Queensland Flora. Government Printer, Brisbane.

Bailey, F.M., 1901--The Queensland Flora 4. Government Printer, Brisbane.

Bailey, F.M., 1913-Comprehensive Catalogue of Queensland Plants. Illus. Government Printer, Brisbane.

Bentham, G., 1870-Flora Australiensis 5. Lovell Reeve \& Co., London.

Domin, K., 1925-Lauraceae. In Beiträge zur Flora und Pflanzengeographie Australiens. Biblioth. Bot. 22: 674-80.

Floyd, A.G., and Hayes, H.C., 1960-New South Wales Rain-forest Trees I. Lauraceae: Forestry Commission of New South Wales, Division of Forest Management, Research Note 3. Sydney.

Francis, W.D., 1929-Australian Rain-forest Trees, ed. 1. Illus. Government Printer, Brisbane.

Francis, W.D., 1951-Ibid., ed. 2. Forestry and Timber Bureau, Canberra.

Kostermans, A.J.G.H., 1969-Materials for a Revision of the Lauraceae. II. Reinwardtia 7 (5): 451-536.

Maiden, J.H., 1907-[Cryptocarya glaucescens.] Forest Flora of New South Wales 3: $125-27$, pl. 104.

Maiden, J.H., and Betche, E., 1895-[Cryptocarya microneura.] Proc. Linn. Soc. New South Wales, ser. 2, 10 (1): 515-16.

Maiden, J.H., and Betche, E., 1916-Census of New South Wales Plants. Government Printer, Sydney.

Meisner, C.F., 1864-Laurineae. In Candolle, A. De, Prodromus Systematis Naturalis Regni Vegetabilis, 15 (1): 1-260. Masson, Paris.

Moore, C., and Betche, E., 1893-Handbook of the Flora of New South Wales. Government Printer, Sydney.

Mueller, F., 1866-[Cryptocarya meissneri.] Fragmenta Phytographiae Australiae, 5: 170. Melbourne.

Mueller, F., 1882-Systematic Census of Australian Plants. Victorian Government, Melbourne.

Mueller, F., 1889-Second Systematic Census of Australian Plants, 1: Vasculares. Government Printer, Melbourne.

\section{APPENDIX}

\section{SYSTEMATIC TREATMENT}

\section{KEY TO THE SPECIES}

1. Leaves with the lower surface markedly glaucous, usually persistently so in dry state Fruits depressed-globose at maturity, broader than long ............. . glaucescens 1.

1.* Leaves with the lower surface not or slightly glaucous (in the latter case not usually persistently so in dry state). Fruits more or less ellipsoid or globose at maturity, never broader than long.

2. Leaves with the reticulum distinctly visible and the surfaces not or very slightly contrasting in colour, the lower surface sometimes glaucous; primary lateral veins usually ascending; midrib on upper surface raised or flush with the surface in dry state. Inflorescences very shortly hairy.

3. Lower surfaces of leaves slightly glaucous (glaucousness often disappearing on drying); primary lateral veins looping and anastomosing near the margin but not noticeably dichotomizing. Young branchlets with persistent

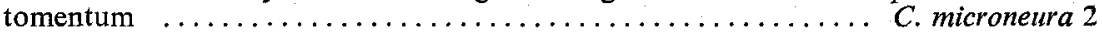


3.* Lower surfaces of leaves never glaucous; primary lateral veins tending to dichotomize $\frac{1}{2}-\frac{2}{3}$ of the way from the margin. Young branchlets soon becoming glabrous $\ldots \ldots \ldots \ldots \ldots \ldots \ldots \ldots \ldots \ldots \ldots \ldots \ldots \ldots, \ldots$, bidwillii 3.

2.* Leaves with the reticulum obscure and the surfaces sharply contrasting in colour (particularly in fresh material), the lower surface rather pale but not glaucous; primary lateral veins spreading; midrib on upper surface usually grooved when dry.

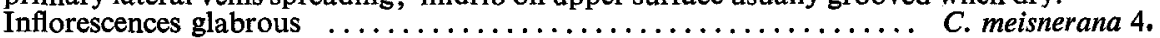

1. Cryptocarya glaucescens $R$. Br., Prodr. Fl. Nov. Holl.: 402, (1810); Meisner in Candolle, Prodr. 15 (1): 72, 78, 508 (1864), quoad typo; Bentham, Fl. Austral. 5: 297 (1870), excl. vars; F. M. Bailey, Queensland Fl. 4: 1299 (1901); Maiden, Forest Fl. New South Wales 3: 125, t. 100 (1907); Maiden \& Betche, Census New South Wales P1.: 81 (1916); Francis, Austral. Rain-forest Trees, ed. 1: 114 (1929), ed. 2: 129 (1957); Anderson, Trees New South Wales, ed. 3: 225, 337 (1957). HoLotyPe: "East Coast"? Hawkesbury River, R. Brown s.n. (BM).

C. moretoniana Meisn. in Candolle, Prodr. 15 (1): 74 (1864), '? moretoniana'. Holotype: QueEnSLAND: Moreton Bay [Brisbane River], Cunningham 48/1829 (K).

C. glaucescens R. Br. var. nitida Benth., Fl. Austral. 5: 297 (1870), p.p.; F. M. Bailey, Queensland Fl. 4: 1300 (1901); Compr. Cat.: 430 (1913); Maiden, Forest Fl. New South Wales 3: 125 (1907). HoLotYPE: Based upon C. moretoniana Meisn.

C. hypoglauca Meisn. var. attenuata Meisn. in Candolle, Prodr. 15 (1): 508 (1864). HoloTYPE: NEW SOUTH WALES: Hastings River, Mueller s.n. (G-DC).

C. meissneri F. Muell., Fragm. 5: 170 (1866), p.p. quoad typo. LeCtotype: the Holotype of C. hypoglauca var. attenuata Meisn.

Distribution: Rain-forests of eastern New South Wales and Queensland; from Milton northwards to Fraser Island and the Wide Bay district but recorded also from the Eungella Range, west of Mackay, and the Stannary Hilis, west of Herberton. Bailey (1901, p. 1299) also mentions Rockhampton as a locality but this is almost certainly based on specimens which in fact represent C. microneura.

Cryptocarya moretoniana Meisn. is based on states of $C$. glaucescens with leaves more or less acute at the apex. Such states are often seen on saplings or subadult trees and occur throughout the range of the species.

Cryptocarya glaucescens var. coriacea Benth. (1870), from North Queensland, is based on specimens collected by Dallachy in the Rockingham Bay district. Examination of type material at $\mathrm{K}$ and MEL shows this to represent two species, both distinct from $C$. glaucescens. One of these is very likely the same as $C$. hypoglauca Meisn., originally described from a specimen supposedly collected by Cunningham but confirmation must await actual examination of the holotype in G-DC.

There is one collection from far north Queensland [Stannary Hills, west of Herberton, Bancroft s.n. (BRI)] which apparently represents $C$. glaucescens. If this locality is correct, it would represent the only known record of the species from that region.

The disposition of C. glaucescens var. reticulata is dealt with under C. microneura.

2. Cryptocarya microneura Meisn. in Candolle, Prodr. 15 (1): 73 (1864); F. Mueller, Fragm. 5: 166 (1866); Maiden \& Baker in Proc. Linn. Soc. New South Wales, ser. 2, 10: 515, t. 42 (1895); Maiden, Forest Fl. New South Wales 3: 111, 144, t. 108 (1907); Maiden \& Betche, Census New South Wales PI.: 81 (1916); Anderson, Trees New South Wales ed. 3: 226, 337 (1957); Francis, Austral. Rain-forest Trees, ed. 1: 115 (1929), ed. 2: 129 (1951); Domin in Biblioth. Bot. 22: 675 (1925). LECTOTYPE: "Colony, 1819", A. Cunningham s.n. (K). $\dagger$

† Since Meisner did not designate a holotype I have chosen, as lectotype, the earlier of the two collections at $\mathrm{K}$ cited by him under the original description. 
Misapplied Names: C. glaucescens var. reticulata auct., non Meisn.: Bentham, Fl. Austral. 5: 297 (1870); F. M. Bailey, Queensland Fl. 4: 1300 (1901); F. M. Bailey, Compr. Cat.: 430 (1913).

C. glaucescens var. nitida Benth., $\mathrm{Fl}$ Austral. 5: 297 (1870), p.p. excl. typ.; Bailey, Queensland Fl. 4: 1300 (1901). PARATYPE: "Archer's Creek", Leichhardt s.n. (K).

C. moretoniana auct., non Meisn.: Francis, Austral. Rain-forest Trees, ed. 2: 129 (1951), pp.

Distribution: Rainforests of eastern New South Wales and Queensland; from Batemans Bay north to Shiptons Flat near Cooktown but only of local occurrence north of the Gympie district.

The leaves of this species are, at least in some forms, naturally slightly glaucous on the under surface; however, this glaucousness tends to disappear on drying and in any case, it is almost never as pronounced as in $C$. glaucescens. Certain trees in Queensland and New South Wales which have hard, shining leaves are sometimes known as $C$. moretoniana or $C$. glaucescens var. nitida and may be classed as a variant (ecotype?) of C. microneura. As far as can be established at present, this form grows in and near the coast from extreme north eastern New South Wales through south eastern Queensland and north to the Proserpine district. It intergrades with the "normal" form of the species in a way which suggests that different habitats may be involved. Pending further study of this situation in field and herbarium I refrain from giving the hard-leaved form taxonomic status at this stage but wish to bring it to the attention of interested workers.

Cryptocarya microneura has, in the past, been equated with $C$. glaucescens var. reticulata Meisn. This latter name was based upon a sterile specimen in the Hookerian herbarium (now K) originally collected by Charles Moore for the Sydney Woods exhibit at the 1862 London Intercolonial Exposition; it actually represents Endiandra sieberi. Within this taxon Bentham (1870) included some additional specimens which belong in $C$. microneura. Among these is another specimen collected by Moore but it is from the Hastings River and was not received at Kew until after the purchase of the Hookerian herbarium in 1867.

3. Cryptocarya bidwillii Meisn. in Candolle, Prodr. 15 (1): 74, 508 (1864); Bentham, Fl. Austral. 5: 297 (1870), in obs., pro syn.; F. M. Bailey, Queensland Fl. 1300 (1901); Maiden, Forest Fl. New South Wales 3: 125 (1907); Kostermans in Reinwardtia 7 (5): 468 (1969). HolotyPe: QueEnsland: Wide Bay, Bidwill $38(\mathrm{~K})$.

MisapPlied NAME: C. moretoniana auct., non Meisn.: Francis, Austral. Rain-forest Trees, ed. 2: 129 (1951), p.p.; Floyd \& Hayes, New South Wales Rain-forest Trees, I, Lauraceae: 22 (1960).

Distribution: North-eastern New South Wales and eastern Queensland; from Glen Ugie Peak near Grafton to the Biggenden district west of Maryborough as well as in the Proserpine district.

This species is distinguished from $C$. microneura most readily by the less conspicuously reticulate, non-glaucous leaves in which the primary veins sometimes dichotomize $\frac{1}{2}-\frac{2}{3}$ way from the margin. In addition $C$. bidwillii is evidently a small tree not exceeding $18 \mathrm{~m}$ in height and is chiefly found in dry rainforests and vine scrubs, whereas $C$. microneura may reach $40 \mathrm{~m}$ in height and generally occurs in moist rainforests.

4. Cryptocarya meisnerana Frodin, sp. nov. Arbor gracilis usque ad $15 \mathrm{~m}$; ramuli teretes (vel in speciminibus siccis leviter angulati), olivaceo-brunnei vel rubido-fusci; folia plerumque elliptica vel elliptico-lanceolata, glabra, tenuiter coriacea (aliquantum in sicco fragilia), pennivenia (aliquando basi subtriplinervia), plus minusve acuminata, basi attenuata, supra fusco-viridia, subtus multo pallidioria, costa supra leviter immersa, subtus parum elevata, venis primariis supra paginae 
complanis (vel in speciminibus siccis perleviter elevatis), subtus parum elevatis, 5-8 cm longa, 2.5-3-plo longiora quam latiora, petioli 3-6 $\mathrm{mm}$ longi; inflorescentiae paulo tenellae, semper axillares, $10-15 \mathrm{~mm}$ longae, plus minusve adpresso-villosae, demum glabrescentes; flores parvi, breviter pedicellati; fructus ellipsoidales, carnosi, rubidi, $9-13 \mathrm{~mm}$ longi, leves.

Slender tree up to $15 \mathrm{~m}$ tall; branchlets terete (or slightly angled in dry specimens), olive-brown or dark red; leaves commonly elliptic or elliptic-lanceolate, glabrous, thinly coriaceous (somewhat brittle when dry), penniveined (sometimes subtriplinerved at base), more or less acuminate, base attenuate, dark green above, much paler beneath, midrib slightly sunken on upper surface, slightly raised beneath, primary veins flush with upper surface (or very slightly elevated in dry specimens), slightly raised beneath, 5-8 cm long, 2.5-3 times as long as broad, petiole 3-6 mm long; inflorescences somewhat delicate, always axillary, 10-15 mm long, more or less appressed-villous, at length glabrescent; flowers small, shortly pedicellate; fruit ellipsoid, fleshy, red, 9-13 mm long, smooth.

Holotype: Hastings River near Port Macquarie, Beckler s.n. (K). IsOtyPe: (MEL).

C. hypoglauca var. attenuata auct., non Meisn.: Bentham, Fl. Austral. 5: 298 (1870); F. M. Bailey, Queensland Fl. 4: 1301 (1901).

This species has been included under the name $C$. meissneri F. Muell. in the following works: F. Mueller, Fragm. 5: 170 (1866), p.p. excl. typ.; Bentham, Fl. Austral. 5: 298 (1870); F. M. Bailey, Queensland Fl. 4: 1301 (1901); Maiden \& Betche, Census New South Wales Pl.: 81 (1916); Anderson, Trees New South Wales, ed. 3: 226, 337 (1957); Francis, Austral. Rainforest Trees, ed. 2: 135 (1951); Floyd \& Hayes, New South Wales Rain-forest Trees I: Lauraceae: 20 (1960).

Distribution: North-eastern New South Wales and extreme south-eastern Queensland; from the Hastings River north to just beyond the Macpherson Range (Logan River).

In the form, coloration and texture of the foliage, inflorescences and, to a lesser extent, the fruits, this species seems to be most closely related to $C$. bowiei (Hook.) Druce [C. laevigata Bl. var. bowiei (Hook.) Kosterm.] It also shows affinities with C. oubatchensis Schltr. of New Caledonia.

Cryptocarya meisnerana is evidently a small, relatively short-lived tree, seldom reaching a height of more than $8 \mathrm{~m}$. In the Dorrigo Plateau of northern New South Wales it is quite common, especially in the ecotonal belts between wet sclerophyll forest (dominated by Eucalyptus microcorys, $E$. saligna, E. grandis and $E$. pilularis) and moist rain-forest. In the rain-forest areas it is often seen along roadsides. However, it does not appear to flower or fruit very freely, although it is sometimes a common species amongst regrowth from cleared rain-forest. 